\title{
Mapping and Quantifying Variations in Ecosystem Services of Urban Green Spaces: A Test Case of Carbon Sequestration at the District Scale for Seoul, Korea (1975-2015)
}

\author{
Yiwen Han ${ }^{1,3}$,Wanmo Kang ${ }^{2}$, Youngkeun Song ${ }^{3 *}$ \\ 1 Graduate School of Environmental Studies, Seoul National University \\ 2 Department of Human Environment Design, Cheongju University \\ 3 Dept. of Landscape Architecture, Graduate School of Environmental Studies, Seoul National \\ University \\ * Corresponding Author, Email: songkoon@snu.ac.kr
}

Received: Jan 2 , 2018; Accepted: Mar 16, 2018

Key words: Social-Ecosystem Services; Landscape Pattern, Green Infrastructure; Historical Changes; Invest Model;

\begin{abstract}
Urban ecosystem services (ESs) can moderate many common environmental issues in cities that are caused by the land use transformation central to urbanization. However, quantitative knowledge of historical changes in ES provisioning at various urban scales is limited. In this research, it is proposed to identify ESs, especially those generated by urban green space (UGS), and quantify their spatiotemporal variations at the regional scale in the southern part of Seoul City, Korea. Changes are first detected in landscape patterns, then one ES indicator - carbon sequestration (CS) - is chosen as a test case, and its spatial pattern explored using the Integrated Valuation of Ecosystem Services and Tradeoffs (InVEST) model. Total potential CS decreased by $41.2 \%$ from 1975 to 2015, with loss and fragmentation of landscapes occurring and patches becoming smaller and simpler in shape in the urban area, as indicated by landscape metrics. Moreover, strong decreases in urban forest and agricultural areas were the primary causes of loss of CS. On the other hand, a 120\% increase in the grassland area somewhat offset these two factors. It is hoped that these results will contribute to cognizance of the potential of historical processes to inform future policy decisions related to green infrastructure and land-use planning.
\end{abstract}

\section{INTRODUCTION}

The concept of ecosystem services (ESs) has developed rapidly over the past two decades. Hundreds of projects and groups are currently working toward better understanding, modeling, valuation, and management of ESs (Costanza et al., 2014). However, previous studies have generally focused on quantifying the ESs of natural and rural landscapes at regional or national scales (Byrd et al., 2015; Martínez-Harms \& Balvanera, 2012), while less than $10 \%$ of all ES publications deal with urban ESs (Derkzen, Teeffelen, \& Verburg, 2015; Gómez-Baggethun \& Barton, 2013; Haase, 2013). Urban ESs can moderate many common environmental issues in cities, such as air pollution, biodiversity loss, and heat stress, as caused by the land-use transformation that occurs during urbanization (Larondelle \& Haase, 2013; $\underline{\mathrm{Li}}$, Y. et al., 2018). 
As a central component of cities' "green infrastructure" (Tratalos et al., 2007; James et al., 2009), urban green space (UGS) provides critical urban ESs for local residents (Wolch, Byrne, \& Newell, 2014). UGS includes many types of space, ranging from high-maintenance urban parks to natural areas and buffer spaces between noisy infrastructure and other land-use types (Panduro \& Veie, 2013). These diverse types of UGS are important for the delivery of social and environmental goods (Young, 2010; Ricard \& Bloniarz, 2006), providing a great benefit to the urban environment; thus, more attention should be paid to UGS.

Previous studies have evaluated the benefits derived from UGS in cities. These studies often estimated the economic value of UGS (Abbott \& Klaiber, 2010; Morancho, 2003), as well as the aesthetic (Southon et al., 2017), environmental (Yang et al., 2017; Sandström, Angelstam, \& Mikusiński, 2006) and social value (Chan, 2017; Dennis \& James, 2017; Barbosa et al., 2007). Several studies have also investigated UGS directly based on ES theory. For example, Derkzen, Teeffelen, and Verburg (2015) quantified the ES of UGS in Amsterdam and Niemela et al. (2010) addressed the most important ES in functional urban regions in Finland through measurement of UGS. However, studies investigating ESs at various urban scales are still limited.

Comprehensive spatiotemporal analyses of the landscape can offer a powerful tool for uncovering historical relationships between human activities and the environment (Fuchs et al., 2016; Grecchi et al., 2014; Li, S., Wang, \& Zhang, 2017; Shahraki et al., 2011; Han et al., 2017), and also provide evidence for urban ecosystem conservation and restoration through analysis of urban ESs from a historical perspective.

This study proposes to identify an indicator of ESs at the regional scale in the metropolitan area of Seoul, Korea, and to quantify spatiotemporal variations therein from 1975 to 2015. The potential for urban habitats to capture and store atmospheric carbon is increasingly important amid growing concerns over the role played by anthropogenic $\mathrm{CO}_{2}$ in global climate change (Grafius et al., 2016; Lee, Lee, \& Lee, 2015). Thus, in this research carbon

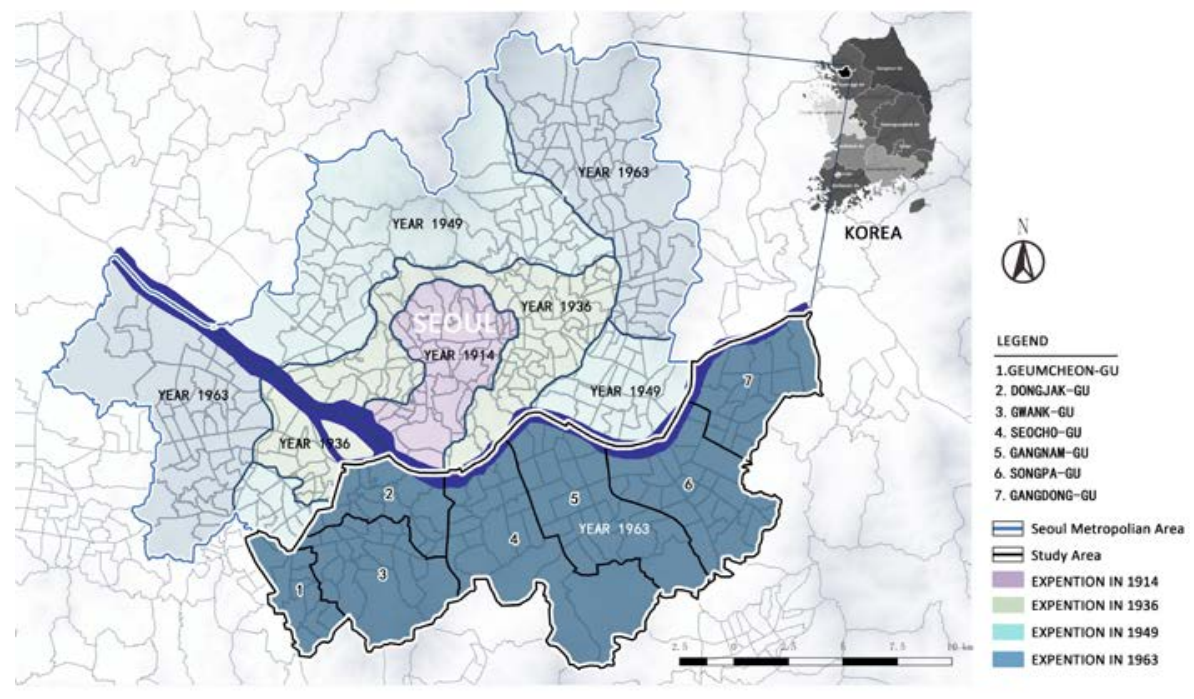

Figure 1. Research site

sequestration (CS) is chosen as a test case, and the response of CS to landscape changes is explored. The study aims to answer three questions: 1) How did the historical landscape change from 1975 to 2015?; 2) What were the 
characteristics of these landscape changes?; and 3) What was the response of CS to historical landscape changes?

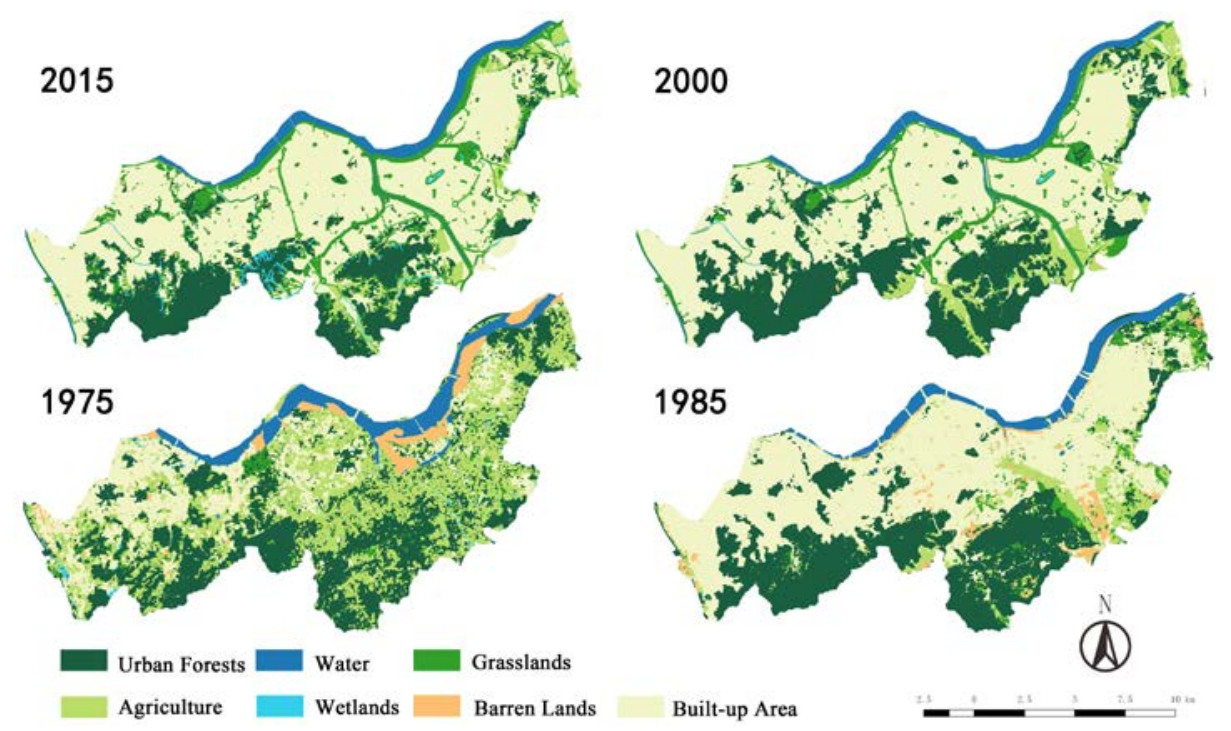

Figure 2. Maps of landscape types from 1975 to 2015

Table 1. Re-classified landscape types classification.

\begin{tabular}{lll} 
NO. & Landscape class & Class description \\
\hline 01 & Urban forests* & Forests or parks with clustering trees in urban areas; orchards. \\
02 & Agriculture* & Cultivated fields, open agricultural lands. \\
03 & Water & Broad-scale rivers and streams. \\
04 & Wetlands & Wetlands, lakes, pools, or irrigation. \\
05 & Grasslands* & $\begin{array}{l}\text { Tombs, creamery parks, golf playgrounds, children's parks, or } \\
\text { grasslands of waterfront areas, parks, and communities. }\end{array}$ \\
06 & Barren lands & $\begin{array}{l}\text { Barren lands, heath, or undeveloped areas without vegetation. } \\
\text { Urban residential, commercial, industrial areas, transportation, or }\end{array}$ \\
07 & Built-up area & \begin{tabular}{l} 
mixed-use areas. \\
\hline
\end{tabular}
\end{tabular}

*Urban green space (UGS) includes landscape types of urban forests, agriculture, and grasslands by referencing to the official land use classification of Seoul.

\section{METHODS}

\subsection{Research site}

This study investigates historical changes in a region that has been expanding and developing since the 1960s in southern Seoul City. Land use in this urban region showed significant changes from the 1960s to 2000s, largely due to the urbanization of peri-urban areas. The study region is approximately 20,430 km2 in area, including Gangdong-gu District, Songpagu District, Gangnam-gu District, Seocho-gu District, Gwanak-gu District, Geumcheon-gu District, and Dongjak-gu District (Figure 1).

\section{$2.2 \quad$ Data}

A time series of land use/cover maps was derived from historical aerial photographs taken in 1975, 1985, 2000, and 2015 containing land cover 
information. The maps for 1975 and 1985 had resolutions of $60 \mathrm{~m}$ and $30 \mathrm{~m}$, respectively, and were created by the Water Management Information System (WAMIS, www.wamis.go.kr). The maps for 2000 and 2015 were provided by the Seoul Metropolitan Government, with $5 \mathrm{~m}$ resolution (www.gis.seoul.go.kr/SeoulGis/). All maps were converted to $5 \mathrm{~m}$ resolution using ArcGIS 10.2.2 software. We then standardized the significant landscape types represented in the maps according to a common classification scheme. The seven re-classified landscape types were: urban forests, agriculture, water, wetlands, grasslands, barren lands, and built-up area (Figure 2, Table 1). Of these newly classified landscape types, three included areas of UGS: urban forests, agriculture, and grasslands.

\subsection{Data analysis}

\subsubsection{Landscape patterns analysis}

Table 2. Landscape metrics using in this study

\begin{tabular}{|c|c|c|c|c|}
\hline Acronym & $\begin{array}{l}\text { Landscape } \\
\text { Metric }\end{array}$ & $\begin{array}{l}\text { Class Level } \\
\text { (UGS) }\end{array}$ & $\begin{array}{l}\text { Landscape } \\
\text { Level }\end{array}$ & Description \\
\hline TLA & $\begin{array}{l}\text { Total } \\
\text { Landscape } \\
\text { Area }\end{array}$ & $\sqrt{ }$ & & The area of each landscape type \\
\hline NumP & $\begin{array}{l}\text { Number of } \\
\text { Patch }\end{array}$ & $\sqrt{ }$ & $\sqrt{ }$ & $\begin{array}{l}\text { Degree of spatial fragmentation of } \\
\text { landscape type; complexity }\end{array}$ \\
\hline MPS & $\begin{array}{l}\text { Mean Patch } \\
\text { Size }\end{array}$ & $\sqrt{ }$ & $\sqrt{ }$ & $\begin{array}{l}\text { Average patch size for a landscape/ } \\
\text { a class }\end{array}$ \\
\hline MSI & $\begin{array}{l}\text { Mean } \\
\text { Shape } \\
\text { Index }\end{array}$ & & $\sqrt{ }$ & $\begin{array}{l}\text { Spatial complexity of a patch's size; } \\
\text { artificial (geometric forms) versus } \\
\text { irregular natural forms }\end{array}$ \\
\hline AWMSI & $\begin{array}{l}\text { Area- } \\
\text { Weighted } \\
\text { Mean } \\
\text { Shape } \\
\text { Index }\end{array}$ & $\sqrt{ }$ & $\sqrt{ }$ & $\begin{array}{l}\text { An average shape index of patches, } \\
\text { weighted by patch area so that large } \\
\text { patches are weighted higher than } \\
\text { smaller ones }\end{array}$ \\
\hline SDI & $\begin{array}{l}\text { Shannon's } \\
\text { Diversity } \\
\text { Index }\end{array}$ & & $\sqrt{ }$ & $\begin{array}{l}\text { SDI increases as the number of } \\
\text { different patch types increases } \\
\text { and/or the proportional distribution } \\
\text { of area among patch types becomes } \\
\text { more equitable. }\end{array}$ \\
\hline
\end{tabular}

To study how landscape changes affect urban ESs, landscape pattern analysis was applied. Landscape metrics have been used previously to analyze spatial characteristics at both the landscape level (i.e., of an entire region) and the class level (of individual UGS) using FRAGSTATS version 4.2.1, a comprehensive software package for analysis at the patch, class, and landscape levels (McGarigal et al., 2002). FRAGSTATS includes a large number of spatial metrics, classified as area and edge metrics, shape metrics, and aggregation metrics. A specific subset of these three categories was selected for this study (Deng et al., 2009). Several landscape metrics, including number of patches (NumP), mean patch size (MPS), mean shape index (MSI), area-weighted mean shape index (AWMSI) and Shannon's diversity index (SDI) were applied herein to clarify changes in overall 
landscape loss and fragmentation trends at the landscape level. At the class level, landscape metrics were useful and directly relevant to correlated changes in UGS. The landscape metrics were calculated for each year and examined, as shown in Table 2.

\subsubsection{Calculating carbon sequestration using InVEST model}

Table 3. Indexes used for carbon model in InVEST software.

\begin{tabular}{lllllll}
\hline NO. & Landscape type & C_ABOVE & C_BELOW & C_SOIL & C_DEAD & Total \\
\hline 1 & Urban forest & 53.59 & 17.36 & 47.22 & 11.79 & 129.96 \\
2 & Agriculture & 0 & 0 & 66.05 & 0 & 66.05 \\
3 & Water & 0 & 0 & 0 & 0 & 0 \\
4 & Wetland & 0 & 0 & 88.00 & 11.00 & 99 \\
5 & Grasslands & 0.33 & 0.89 & 88.20 & 0.20 & 89.62 \\
6 & Barren lands & 0 & 0.33 & 0.33 & 0 & 0.66 \\
7 & Built-up area & 0 & 0 & 0 & 0 & 0 \\
\hline
\end{tabular}

* The unit is $\mathrm{t} \mathrm{C} / \mathrm{ha}$

The amount of CS during four historical periods in the study area was assessed using the Integrated Valuation of Ecosystem Services and Tradeoffs (InVEST) model. InVEST was developed as part of the Natural Capital Project (www.naturalcapitalproject.org) by Stanford University, he University of Minnesota, The Nature Conservancy, and the World Wildlife Fund. InVEST uses maps of landscape types, which also detail the amount of carbon stored in carbon pools, to estimate the net amount of carbon stored in a given parcel of land (see InVEST user's guide for further details on this method) (Sharp et al., 2014).

The CS module requires an estimate of the amount of carbon in at least one of the four fundamental carbon pools: above-ground biomass, belowground biomass, soil organic matter, and dead organic matter. Aboveground biomass comprises all above-soil living plant material; belowground biomass encompasses the living root systems attached to the aboveground biomass; soil organic matter, the largest terrestrial carbon pool, is the organic component of soil; dead organic matter includes litter, as well as lying and standing dead wood (Sharp et al., 2014). All four fundamental pools were examined in this study. The CS index was derived from previous studies (Chung, Kang, \& Choi, 2015; Tomasso \& Leighton, 2014; National Institute of Forest Science (NIFoS), 2015; Korea Environment Institute (KEI), 2016)(Table 3); Based on the input parameters, the total CS for each period examined was quantified.

\section{RESULTS AND DISSCUSSION}

\subsection{Detection of historical changes in urban landscape}

Seoul experienced rapid urbanization between the 1960s and the 1990s, with landscape changes occurring as a result of numerous projects, and with little consideration for the natural environment (Hong et al., 2003). Data on the areas covered by each landscape type in the four years examined in this study are presented in Figure 3. The most significant change was in the large 
areas of natural landscape that were lost with the dramatic increase in construction area (Han et al., 2017). Built-up area covered approximately 19,384 ha in 2015, compared with 6,365 ha in 1975 (Figure 3). The second most significant change occurred in the agricultural landscape: the proportion of agricultural land decreased by $90 \%$ over the 40 -year period and (Figure 3), by 2015, only a small amount of agricultural land remained on the outskirts of the district (see Figure 2).

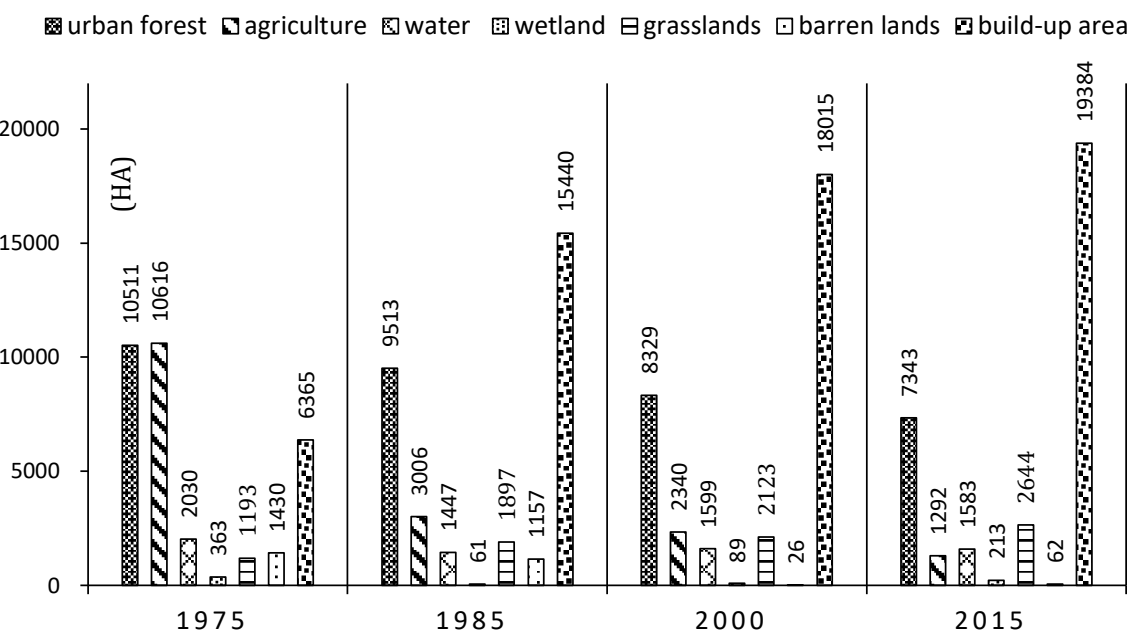

Figure 3. The total landscape area (TLA) of each landscape type from 1975 to 2015

Significant changes in landscape type occurred during the period 1975 1985. The agricultural landscape declined in extent by approximately $72 \%$, while the amount of built-up area increased significantly (Figure 3). Most of the rural landscape was urbanized during this period. In addition, after the 1990s, although the process of urban transformation slowed, forest area still decreased between the years of 2000 and 2015, while the built-up area increased steadily.

UGS in the study area changed significantly, as indicated by the proportions of the urban forest, agriculture, and grassland landscape types. The area covered by urban forests decreased by about $30 \%$, while that covered by grasslands increased by approximately $120 \%$; most of the grasslands had previously been forest and agricultural lands (Figure 3). This shift may be attributable to the "Parks Act", enacted in the 1980s, which had the goal of enhancing urban greenness via park-related laws, and which transformed cultural and historical sites into neighborhood parks.

In addition, a trend toward urban landscape fragmentation was indicated by the NumP and MPS values. At the landscape level, the overall NumP increased from 7,127 in 1975 to 8,832 in 2015. MPS showed its highest value (7.096) in 2000, but this decreased by approximately 50\% (3.682) by 2015 (Figure 4). The fragmentation trend can also be explained by reference to the 

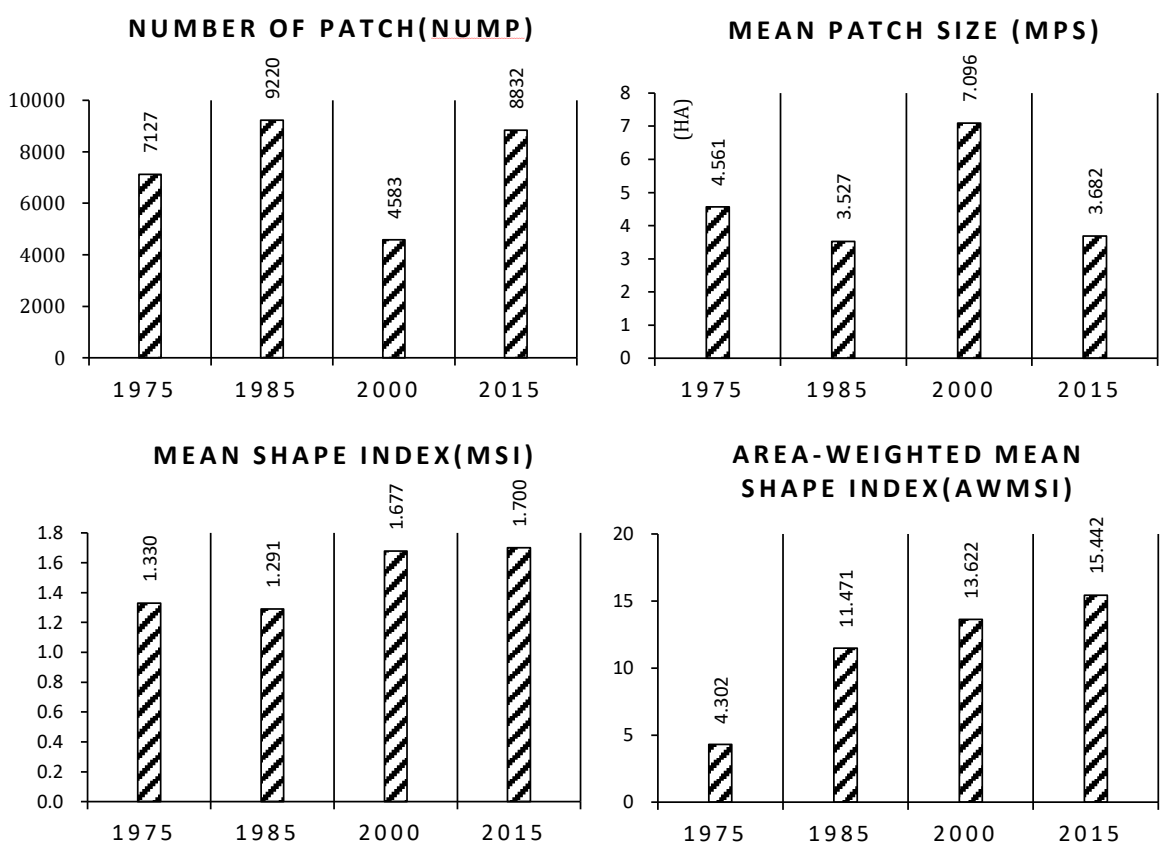

SHANNON'S DIVERSITY INDEX(SDI)

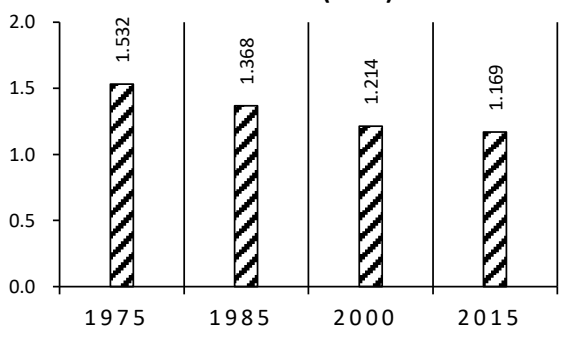

Figure 4.The results of examined landscape metrics at landscape level from 1975 to 2015

spatial metrics of UGS at the class level (Figure 5). Urban forests were present in only 2,188 patches in 1975, compared with 4,844 patches in 2015. The NumP of agriculture decreased steadily, from 2,037 patches in 1975 to 744 patches in 2015, except in 1985(2,557), when it increased slightly. Meanwhile, the NumP of grasslands increased from 920 in 1975 to 3,431 in 1985 , but then decreased to 1,498 in 2000 , before finally increasing again to 2,798 in 2015.

Moreover, the diversity of patch types decreased, while the shapes of patches became simpler, and the patch size smaller. At the landscape level, AWMSI increased from 4.302 in 1975 to 15.442 in 2015, and SDI decreased from 1.532 in 1975 to 1.169 in 2015 (Figure 4). However, UGS at the class level shows different results, both in terms of landscape types and year of study. For example, a previous study reported that forest patches decreased during the period 1988-1999 and patch shapes became smaller and simpler (Hong et al., 2003), as indicated in this study by the sharp declines in MPS and AWMSI from 1985 to 2000; however, AWMSI showed a contrary trend for the period 2000-2015, with a slight increase from 1.669 to 2.025 (Figure 5).

\subsection{Historical changes of carbon sequestration (CS)}

Land use transformation affects the CS capability of urban areas. The total potential CS in the study area decreased by $41.2 \%$ from 1975 to 


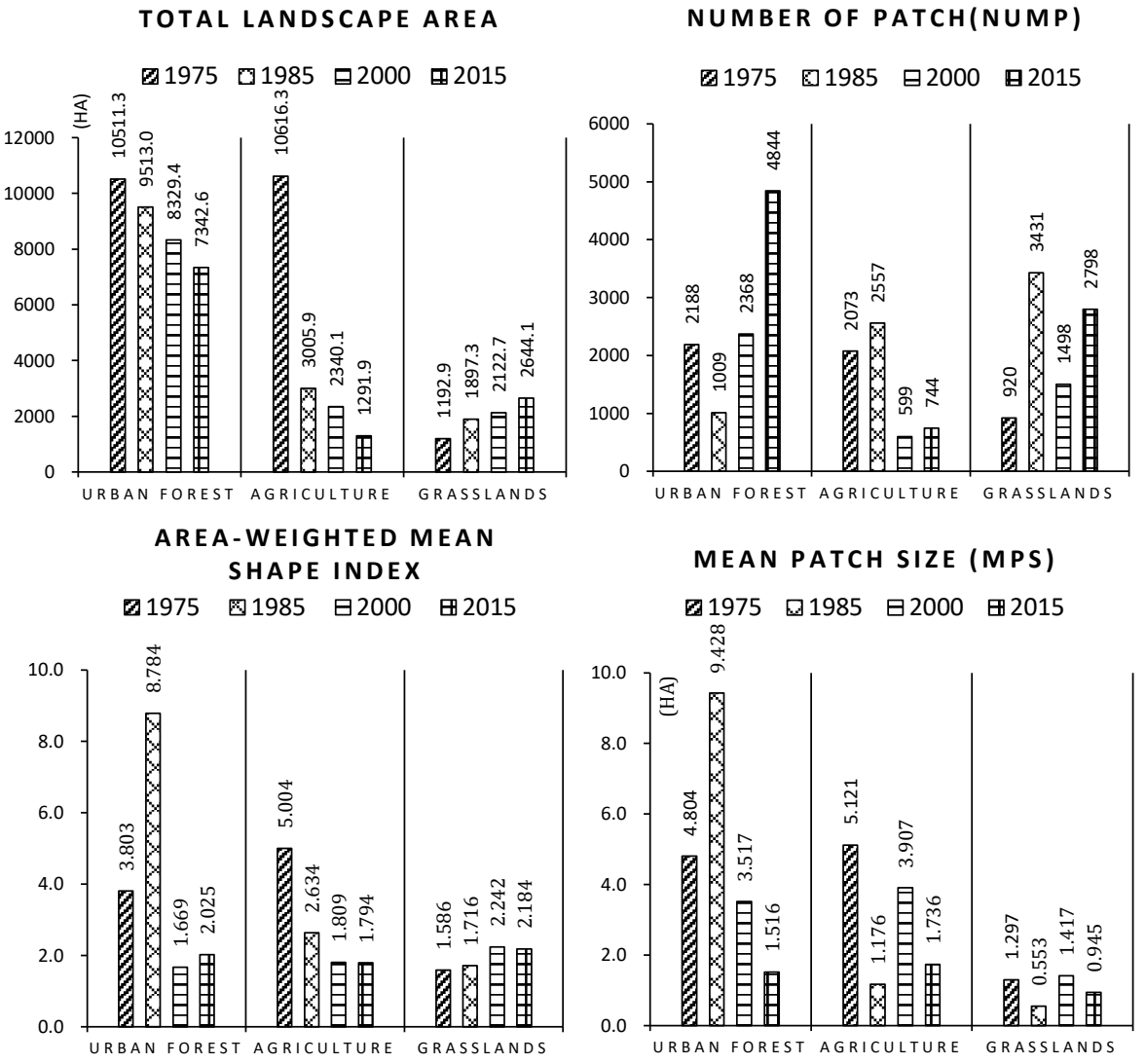

Figure 5.The results of examined landscape metrics of UGS (urban forest, agriculture, grasslands) at class level from 1975 to 2015.

2015(Table 4). UGS provides important ecosystem-related goods and services at the city level, and plays a particularly critical role in CS. Thus, in this study, the decline in the area of UGS was the main cause for the loss of CS. The proportion of UGS relative to the total study area decreased from $95.5 \%$ in 1975 to $81.6 \%$ in 2015(Table 4). Urban forests decreased by 30\%, which was the main reason for the decrease in CS, as urban forests and urban soils can significantly increase $\mathrm{CO}_{2}$ sequestration and storage (Pulighe, Fava, \& Lupia, 2016). Urban agriculture contributed to storage of $\mathrm{CO}_{2}$ in gardens, and could decrease greenhouse gas production in relation to the distance over which food is transported to reach consumers. Our results show that the agricultural landscape in the study area decreased by $90 \%$ from 1975 to 2015 . Lee, Lee, and Lee (2015) explored the area available for urban farming in the metropolitan area of Seoul, and concluded that urban agriculture in a 51.15 $\mathrm{km}^{2}$ area within Seoul City could reduce $\mathrm{CO}_{2}$ emissions by 11.67 million $\mathrm{kg}$ annually.The $120 \%$ increase in the area of grasslands, which somewhat offset the decreases in agriculture and urban forests, was mainly in the form of urban green infrastructure, such as parks and community gardens.

Table 4. The historical changes of carbon sequestration

\begin{tabular}{lllll}
\hline Year & 1975 & 1985 & 2000 & 2015 \\
\hline Total CS (ton) & 1387427.88 & 1012851.47 & 902769.47 & 815535.81 \\
CS of UGS & 1317770.62 & 904879.89 & 782688.05 & 665533.74 \\
Proportion & $95.5 \%$ & $89.3 \%$ & $86.7 \%$ & $81.6 \%$ \\
\hline
\end{tabular}




\subsection{The role and applications of UGS in ecosystem services (ESs)}

For certain ESs, the spatial arrangement of UGS is a key determinant of whether a service is actually supplied (Andersson et al., 2015). The type, size, and location of UGS affect ESs supply in different ways. For example, whether a city has a few large or many small habitat areas does not matter in terms of CS, although long and continuous vegetation strips are optimal for noise reduction (McGarigal et al., 2002).

Through mapping the landscape patterns in the research area, the fragmentation of natural habitats was shown to be due mainly to the process of urbanization. CS in the study area decreased by $41.2 \%$ from 1975 to 2015(Table 4). Natural habitat was found to be the UGS type playing the most crucial role in CS. Thus, consideration of the potential for UGS to capture and store atmospheric carbon in urban areas is essential (Darren et al., 2016).

It is also important to differentiate among UGS types when quantifying ESs in an urban area (Pulighe, Fava, \& Lupia, 2016). Although urban forests play an active role in most ecosystem functions, artificial green spaces, such as parks and community gardens, could support several ESs when the forested area shows a sharp decrease. Thus, the importance of careful UGS design during city planning initiatives for the provision of ESs should be highlighted. Moreover, further consideration should be given to enhancing the CS capability of UGS during urban planning and policy making. It's hoped that this study will contribute to a greater understanding of the potential of historical processes to inform future policy decisions related to green infrastructure and land-use planning.

\section{CONCLUSION}

Based on historical changes in landscape types, variations in ESs can be quantified. However, the number of studies clarifying and characterizing ES variations at various urban scales is still limited. Using CS as a test case, we historical changes in ESs were analyzed at the regional scale in Seoul based on changes in landscape patterns from 1975 to 2015. Our results reveal that total potential CS in the study area decreased by $41.2 \%$ between 1975 and 2015, with loss and fragmentation of landscapes and smaller and simpler patch shapes appearing in the urban area, as indicated by landscape metrics. UGS played a crucial role in CS at the city level; thus, a sharp decrease in urban forest and agriculture areas was the main cause of CS loss, although a 120\% increase in the area of grasslands in part offset these two decrease. The size, shape, and spatial arrangement of UGS, especially in the grassland landscape type, affected ESs in different ways, which should be considered in future policy-making and green infrastructure planning initiatives. These findings contribute to the evidence that historical maps are useful for analyzing temporal dynamics and the trajectory of landscape changes, and provide important insights for the conservation of natural habitats in the central urban area of Seoul. However, limitations to the CS model used in this study remain, including an oversimplified carbon cycle, the assumption of linear change in CS over time, and potentially inaccurate discounting rates (Sharp et al., 2014). Further studies should explore the relationship between changes in landscape patterns and multiple ESs. 


\section{ACKNOWLEDGMENTS}

This work was supported by the BK21 plus Project in 2018 (Seoul National University Interdisciplinary Program in Landscape Architecture, Global Leadership Program towards Innovative Green Infrastructure).

\section{REFERENCES}

Abbott, J. K., \& Klaiber, H. A. (2010). "Is All Space Created Equal? Uncovering the Relationship between Competing Land Uses in Subdivisions". Ecological Economics, 70(2), 296-307.

Andersson, E., McPhearson, T., Kremer, P., Gomez-Baggethun, E., Haase, D., Tuvendal, M., \& Wurster, D. (2015). "Scale and Context Dependence of Ecosystem Service Providing Units". Ecosystem Services, 12, 157-164.

Barbosa, O., Tratalos, J. A., Armsworth, P. R., Davies, R. G., Fuller, R. A., Johnson, P., \& Gaston, K. J. (2007). "Who Benefits from Access to Green Space? A Case Study from Sheffield, Uk". Landscape and Urban planning, 83(2), 187-195.

Byrd, K. B., Flint, L. E., Alvarez, P., Casey, C. F., Sleeter, B. M., Soulard, C. E., . . S Sohl, T. L. (2015). "Integrated Climate and Land Use Change Scenarios for California Rangeland Ecosystem Services: Wildlife Habitat, Soil Carbon, and Water Supply". Landscape Ecology, 30(4), 729-750.

Chan, C.-S. (2017). "Health-Related Elements in Green Space Branding in Hong Kong". Urban Forestry \& Urban Greening, 21, 192-202.

Chung, M. G., Kang, H., \& Choi, S. U. (2015). "Assessment of Coastal Ecosystem Services for Conservation Strategies in South Korea". Plos One, 10(7), e0133856.

Costanza, R., de Groot, R., Sutton, P., van der Ploeg, S., Anderson, S. J., Kubiszewski, I., . . Turner, R. K. (2014). "Changes in the Global Value of Ecosystem Services". Global Environmental Change, 26, 152-158.

Darren, D. S. A., Petruccelli, D., Patton, S. J., Winemaker, M., \& de Beer, J. (2016). "From "Surgical Gatekeepers" to "Patient Navigators": Examining Perceptions and Practices of Hip and Knee Osteoarthritis Management among Primary Healthcare Physicians". Current Orthopaedic Practice, 27(1), 46-55.

Deng, J. S., Wang, K., Hong, Y., \& Qi, J. G. (2009). "Spatio-Temporal Dynamics and Evolution of Land Use Change and Landscape Pattern in Response to Rapid Urbanization". Landscape and Urban Planning, 92(3-4), 187-198.

Dennis, M., \& James, P. (2017). "Evaluating the Relative Influence on Population Health of Domestic Gardens and Green Space Along a Rural-Urban Gradient". Landscape and Urban Planning, 157, 343-351.

Derkzen, M. L., Teeffelen, A. J., \& Verburg, P. H. (2015). "Review: Quantifying Urban Ecosystem Services Based on High-Resolution Data of Urban Green Space: An Assessment for Rotterdam, the Netherlands". Journal of Applied Ecology, 52(4), 1020-1032.

Fuchs, R., Schulp, C. J., Hengeveld, G. M., Verburg, P. H., Clevers, J. G., Schelhaas, M. J., \& Herold, M. (2016). "Assessing the Influence of Historic Net and Gross Land Changes on the Carbon Fluxes of Europe". Global change biology, 22(7), 2526-2539.

Gómez-Baggethun, E., \& Barton, D. N. (2013). "Classifying and Valuing Ecosystem Services for Urban Planning". Ecological Economics, 86, 235-245.

Grafius, D. R., Corstanje, R., Warren, P. H., Evans, K. L., Hancock, S., \& Harris, J. A. (2016). "The Impact of Land Use/Land Cover Scale on Modelling Urban Ecosystem Services". Landscape Ecology, 31(7), 1509-1522.

Grecchi, R. C., Gwyn, Q. H. J., Benie, G. B., Formaggio, A. R., \& Fahl, F. C. (2014). "Land Use and Land Cover Changes in the Brazilian Cerrado: A Multidisciplinary Approach to Assess the Impacts of Agricultural Expansion". Applied Geography, 55, 300-312.

Haase, D. (2013). "Synthesizing Different Perspectives on the Value of Urban Ecosystem Services". $\quad$ Retrieved from http://sendzimir.org.pl/sites/default/files/Urban\%20Ecosystem\%20Services\%20Lodz\%20 Poland\%2015_16\%20July\%202011\%20book\%20of\%20abstracts\%205.pdf.

Han, Y., Song, Y., Burnette, L., \& Lammers, D. (2017). "Spatiotemporal Analysis of the Formation of Informal Settlements in a Metropolitan Fringe: Seoul (1950-2015)". Sustainability, 9(7), 1190. 
Hong, S. K., Song, I. J., Kim, H. O., \& Lee, E. K. (2003). "Landscape Pattern and Its Effect on Ecosystem Functions in Seoul Metropolitan Area: Urban Ecology on Distribution of the Naturalized Plant Species". Journal of Environmental Sciences, 15(2), 199-204.

James, P., Tzoulas, K., Adams, M. D., Barber, A., Box, J., Breuste, J., . . . Thompson, C. W. (2009). "Towards an Integrated Understanding of Green Space in the European Built Environment". Urban Forestry \& Urban Greening, 8(2), 65-75.

Korea Environment Institute (KEI). (2016). "An Integrated Approach to Environmental Valuation, Sejong-Si, Korea".

Larondelle, N., \& Haase, D. (2013). "Urban Ecosystem Services Assessment Along a RuralUrban Gradient: A Cross-Analysis of European Cities". Ecological Indicators, 29, 179-190.

Lee, G. G., Lee, H. W., \& Lee, J. H. (2015). "Greenhouse Gas Emission Reduction Effect in the Transportation Sector by Urban Agriculture in Seoul, Korea". Landscape and Urban Planning, 140, 1-7.

Li, S., Wang, Z., \& Zhang, Y. (2017). "Crop Cover Reconstruction and Its Effects on Sediment Retention in the Tibetan Plateau for 1900-2000". Journal of Geographical Sciences, 27(7), 786-800.

Li, Y., Kang, W., Han, Y., \& Song, Y. (2018). "Spatial and Temporal Patterns of Microclimates at an Urban Forest Edge and Their Management Implications". Environmental monitoring and assessment, 190(2), 93.

Martínez-Harms, M. J., \& Balvanera, P. (2012). "Methods for Mapping Ecosystem Service Supply: A Review". International Journal of Biodiversity Science, Ecosystem Services \& Management, 8(1-2), 17-25.

McGarigal, K., Cushman, S. A., Neel, M. C., \& Ene, E. (2002). "Fragstats: Spatial Pattern Analysis Program for Categorical Maps". Retrieved from http://www.umass.edu/landeco/research/fragstats/fragstats.html.

Morancho, A. B. (2003). "A Hedonic Valuation of Urban Green Areas". Landscape and Urban Planning, 66(1), 35-41.

National Institute of Forest Science (NIFoS). (2015). "Increased Reliability in Statistics on Forest Carbon Pools of Korea".

Panduro, T. E., \& Veie, K. L. (2013). "Classification and Valuation of Urban Green Spacesa Hedonic House Price Valuation". Landscape and Urban planning, 120, 119-128.

Pulighe, G., Fava, F., \& Lupia, F. (2016). "Insights and Opportunities from Mapping Ecosystem Services of Urban Green Spaces and Potentials in Planning". Ecosystem Services, 22(Part A), 1-10.

Ricard, R. M., \& Bloniarz, D. V. (2006). "Learning Preferences, Job Satisfaction, Community Interactions, and Urban Forestry Practices of New England (USA) Tree Wardens". Urban Forestry \& Urban Greening, 5(1), 1-15.

Sandström, U. G., Angelstam, P., \& Mikusiński, G. (2006). "Ecological Diversity of Birds in Relation to the Structure of Urban Green Space". Landscape and Urban Planning, 77(1-2), 39-53.

Shahraki, S. Z., Sauri, D., Serra, P., Modugno, S., Seifolddini, F., \& Pourahmad, A. (2011). "Urban Sprawl Pattern and Land-Use Change Detection in Yazd, Iran". Habitat International, 35(4), 521-528.

Sharp, R., Tallis, H., Ricketts, T., Guerry, A., Wood, S., Chaplin-Kramer, R., . . . Olwero, N. (2014). "Invest User’s Guide". The Natural Capital Project, Stanford.

Southon, G. E., Jorgensen, A., Dunnett, N., Hoyle, H., \& Evans, K. L. (2017). "Biodiverse Perennial Meadows Have Aesthetic Value and Increase Residents' Perceptions of Site Quality in Urban Green-Space". Landscape and Urban Planning, 158, 105-118.

Tomasso, L. P., \& Leighton, M. (2014). "The Impact of Land Use Change for Greenhouse Gas Inventories and State-Level Climate Mediation Policy: A Gis Methodology Applied to Connecticut". Journal of Environmental Protection, 5(17), 1572-1587.

Tratalos, J., Fuller, R. A., Warren, P. H., Davies, R. G., \& Gaston, K. J. (2007). "Urban Form, Biodiversity Potential and Ecosystem Services". Landscape and urban planning, 83(4), 308317.

Wolch, J. R., Byrne, J., \& Newell, J. P. (2014). "Urban Green Space, Public Health, and Environmental Justice: The Challenge of Making Cities 'Just Green Enough’". Landscape and Urban Planning, 125, 234-244.

Yang, J., Sun, J., Ge, Q., \& Li, X. (2017). "Assessing the Impacts of Urbanization-Associated Green Space on Urban Land Surface Temperature: A Case Study of Dalian, China". Urban Forestry \& Urban Greening, 22, 1-10.

Young, R. F. (2010). "Managing Municipal Green Space for Ecosystem Services". Urban Forestry \& Urban Greening, 9(4), 313-321. 